INTERNATIONAL JOURNAL OF MULTIDISCIPLINARY RESEARCH AND ANALYSis

ISSN(print): 2643-9840, ISSN(online): 2643-9875

Volume 04 Issue 01 January 2021

DOI: 10.47191/ijmra/v4-i1-07, Impact Factor: 5.522

Page No.- $46-53$

\title{
Capital Structure Evaluation, Business Size and Firms' Facility of Food and Beverage Firms Listed on the Hanoi Stock Exchange
}

\author{
Nguyen Van Thu ${ }^{1}$, Nguyen Thi Bich Thuy ${ }^{2}$, Doan Thi Nguyet Ngoc $^{3}$ \\ ${ }^{1,3}$ Faculty of Accounting, University of Labor and Social Affairs, Vietnam \\ ${ }^{2}$ Faculty of Economics, Vinh University, Vietnam
}

\begin{abstract}
The study investigates capital structure, business size and firms' facility of food and beverage firms listed on the Hanoi Stock Exchange (HNX). The study employs a set of aggregated data from 15 food and beverage firms listed on the HNX. At the same time, the study also receives comments from experts experienced in the research field. We have performed some descriptive analysis, compared and correlation analysis with support by software Stata13 to evaluate and measure capital structure, business size and firms' facility of food and beverage firms listed on the Hanoi Stock Exchange (HNX). The results show that there is a difference in capital structure, business size and firms' facility of food and beverage firms listed on the Hanoi Stock Exchange (HNX). Firms with $10 \%$ or more foreign ownership account for a relatively low proportion of these enterprises.
\end{abstract}

KEYWORDS: capital structure, business size, facility, finance

JEL codes: G32, O16, P33, P45

\section{INTRODUCTION}

Regional and global economic integration opens up many opportunities for food and beverage (F\&B) firms in Vietnam to develop product consuming markets, to inherit and apply modern technologies as well as production processes from foreign businesses in developed countries. However, the competition pressure will be stronger and more intense, requiring F\&B firms in Vietnam to have appropriate production and business strategies, especially focusing on financial management in general, management in capital structure, business size and facilities in particular. Otherwise, F\&B firms might face many difficulties or even fail at home market.

In the period 2006 - 2007, many Vietnamese enterprises easily raised their capital by stock issuance due to the boom of the stock market. However, the regular excess increase in equity compared to the need of investment expansion, fixed assets and working assets has affected the capital structure of many enterprises which can be seen through the incurred cost of capital and low capital efficiency.

Capital structure is considered one of the most important topics that have been studied by theories and literature of finance and accounting. These theories have been used to stipulate not only the best mix, but also to explain the factors that determine the capital structure, as well as guiding firms to make decision, which lead to optimal capital structure) (Khan et al, 2020.

From the above reasons, it is necessary to evaluate capital structure, the size of the business and the facilities of F\&B firms listed on the HNX in order to enhance the financial capacity of these businesses.

\section{THEORETICAL BACKGROUND AND LITERATURE REVIEW}

Modigliani and Miller (1958) proposed capital structure irrelevance theory. They concluded that the firm mode of financing does not affect its market value. Modigliani and Miller (1963) reconsidered their idea and suggested that tax benefits are significant factors, which have an impact on the firm's capital structure decisions.

Capital structure refers to the interrelationship of different sources of financing within firms (Brigham \& Houston, 2004). Pham (2011) mentioned the impact of capital structure on efficiency of capital used to generate profits for shareholders according to the Dupont model. The author suggested a direction to build a loan structure for Vietnamese road traffic enterprises. 


\section{Capital Structure Evaluation, Business Size and Firms' Facility of Food and Beverage Firms Listed on the Hanoi Stock Exchange}

Vu (2014) tested specific factors for the operational nature and model of State Economic Groups in the period 2007 - 2012 including: (i) the level of involvement in the field of main activities of the Group, (ii) equity structure. The research results are the basis for the author to propose solutions for capital restructuring of enterprises of Vietnam National Oil and Gas Group.

Koralun-Bereźnicka (2018) analyzed 11 European Union countries data to establish the relationship between capital structure and its determinants.

Inheriting previous studies, this study uses a mixed research method to evaluate capital structure, the size of the business and the facilities of F\&B firms listed on the HNX in the period 2015-2019. The research results could contribute to analyzing the financial situation of enterprises and are meaningful for enterprise managers to make effective business decisions.

\section{METHODOLOGY}

The research uses both qualitative and quantitative research methods.

The qualitative research method including: Interviewed experts and collected the secondary data. We interviewed experts who are leading lecturers in finance and accounting; financial directors in F\&B firms. After that, the study uses balance sheet data, data collected by subjects and by time - series. The secondary data collected from the audited financial statements of 15 food firms listed on HNX in operation by the end of the accounting year 2019 on such reputable website https://finance.vietstock.vn/; cafef.vn/. Thus, this study has 15 firms $* 5$ years $=75$ observed variables, which have been processed and cleaned with Excel.

The observed variable of capital structure was debt to equity ratio (CS3); the observed variable of business size was revenue (S1); the observed variable of facility was density of fixed assets (IET1).

For the quantitative research method, the supporting tool is Stata13 including: descriptive analysis, compared and correlation analysis. Data were tested for normal distribution, used Histogram's chart, results were presented in figure 1 to figure 3. Figures 1 to 3 figure show that, distributed data, fully qualified analysis
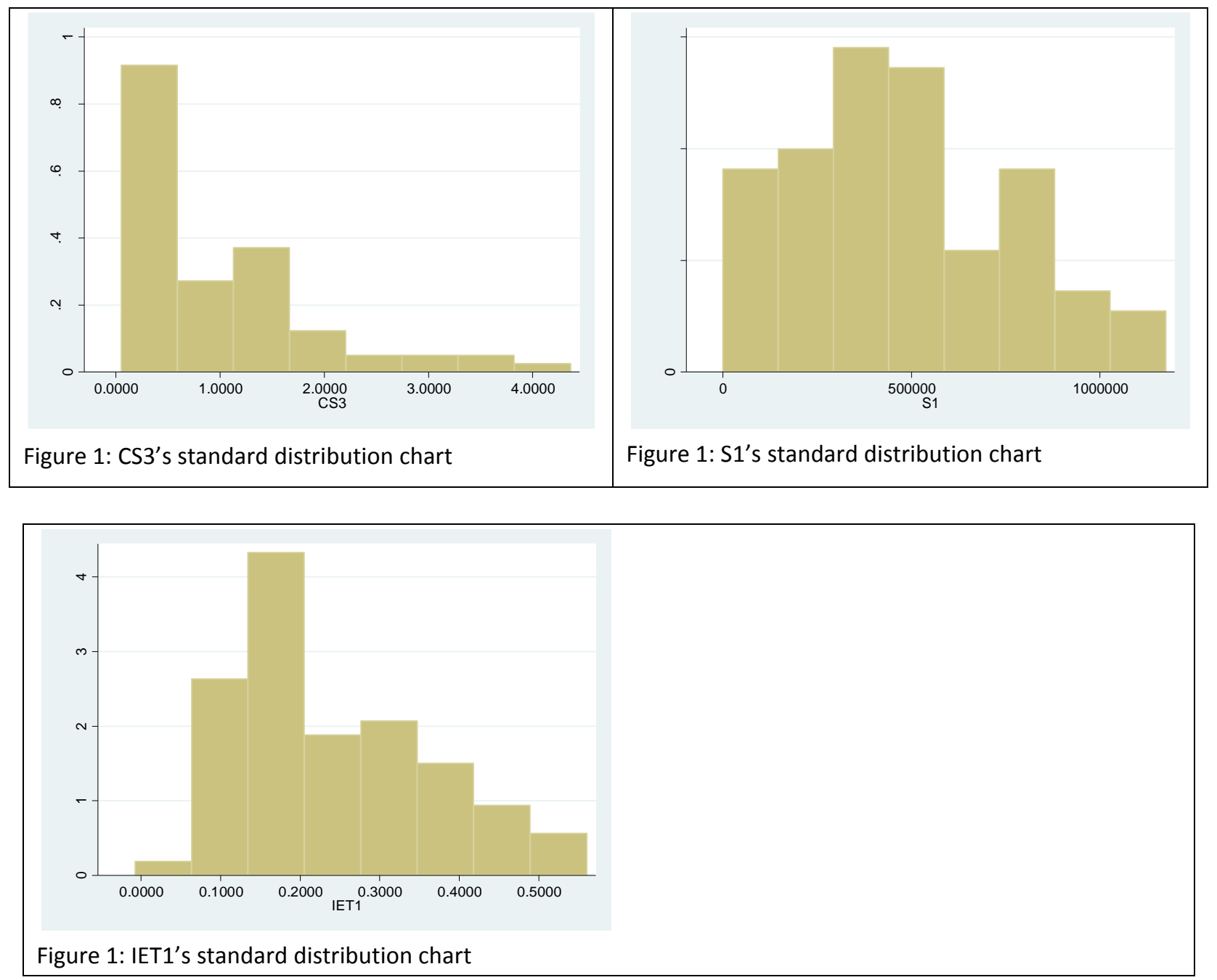
Capital Structure Evaluation, Business Size and Firms' Facility of Food and Beverage Firms Listed on the Hanoi Stock Exchange

\section{RESEARCH RESULTS AND DISCUSSION}

4.1. Descriptive statistics results

Table 1: General descriptive statistics of capital structure, business size and firms' facility of F\&B firms

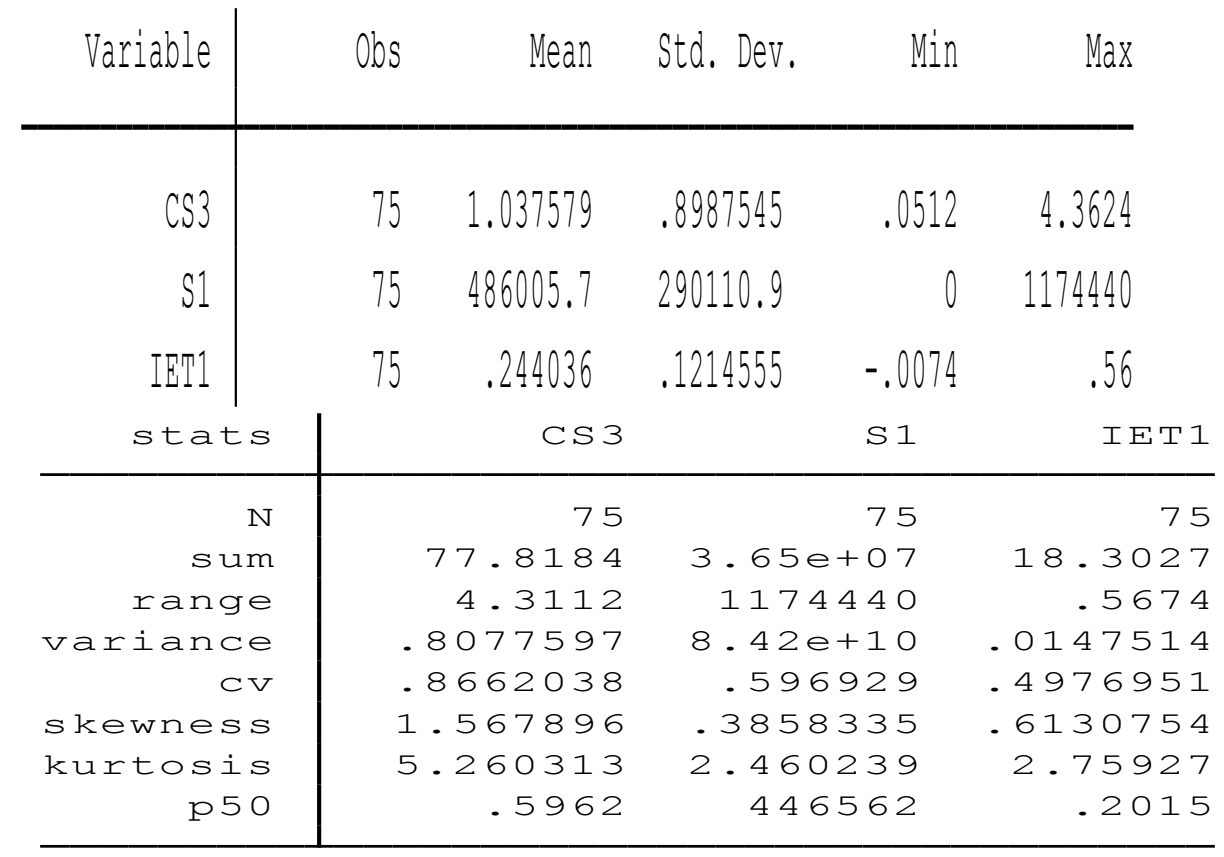

Sources: Stata Sofware 13

Table 1 shows: There are 3 finance indicators, each of which is described by 75 observations (obs); basic indicators such as average value (mean), maximum value (max), minimum value (min), standard deviation (sd), variance, skewness, kurtosis, p50, range, coefficient of variation (cv) of each index have been identified and these basic indicators accurately reflect the current capital structure, business size and firms' facility of F\&B firms listed on the HNX.

Comparison the capital structure, business size and firms' facility between firms with $10 \%$ or more foreign ownership and the rest of firms.

Foreign ownership (CS): The dummy variable is 1 if the enterprise has foreign ownership participation of $10 \%$ or more. The variable for the rest of firms is zero (0).

Table 2: Comparison capital structure (CS3) between firms with $10 \%$ or more foreign ownership and the rest of firms . ttest CS3, by (CS)

Two-sample $t$ test with equal variances

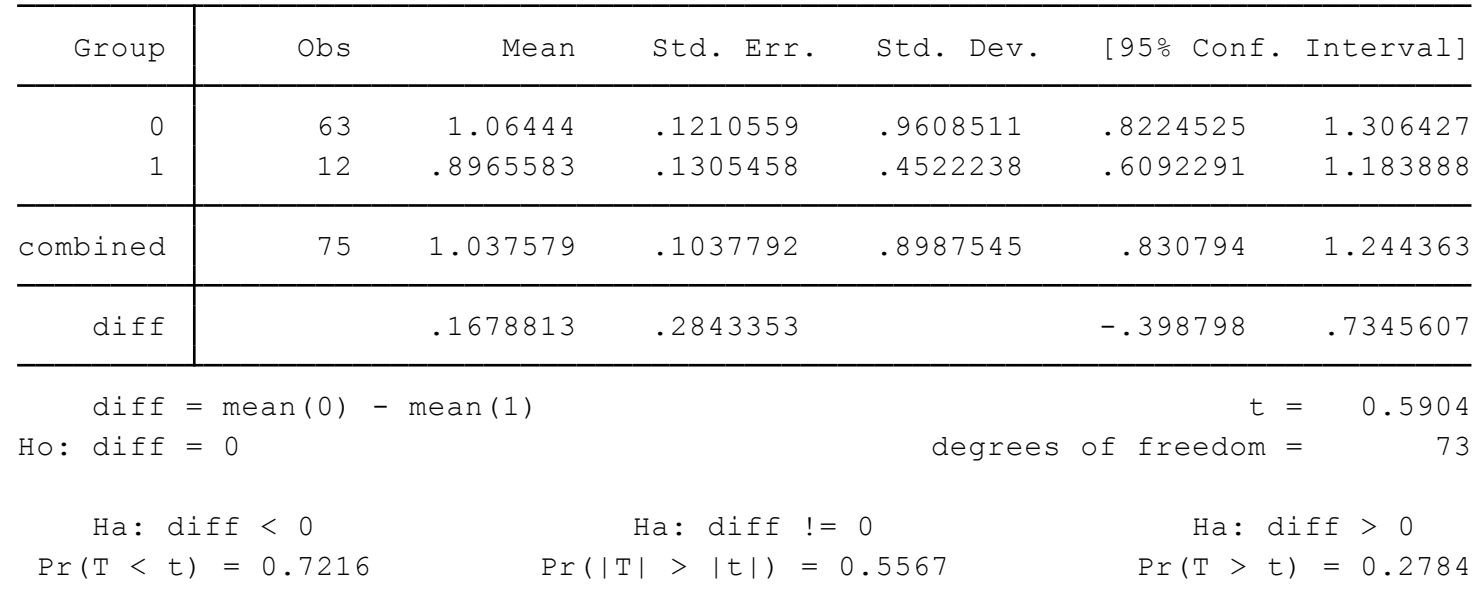

Sources: Stata Sofware 13 


\section{Capital Structure Evaluation, Business Size and Firms' Facility of Food and Beverage Firms Listed on the Hanoi Stock Exchange}

The results in Table 2 shows: There are 12 times of enterprises with foreign ownership participation of $10 \%$ or more; Enterprises with $10 \%$ or above of foreign ownership have a lower CS3 than others do. However, the difference of CS3 between over $10 \%$ foreign owned enterprises and the remaining enterprises is not statistically significant ( $p$-value $=0.5567>0.05$, difference value 0.1678813).

Table 3: Comparison business size (S1) between firms with $10 \%$ or more foreign ownership and the rest of firms . ttest $\mathrm{S} 1$, by (CS)

Two-sample $t$ test with equal variances

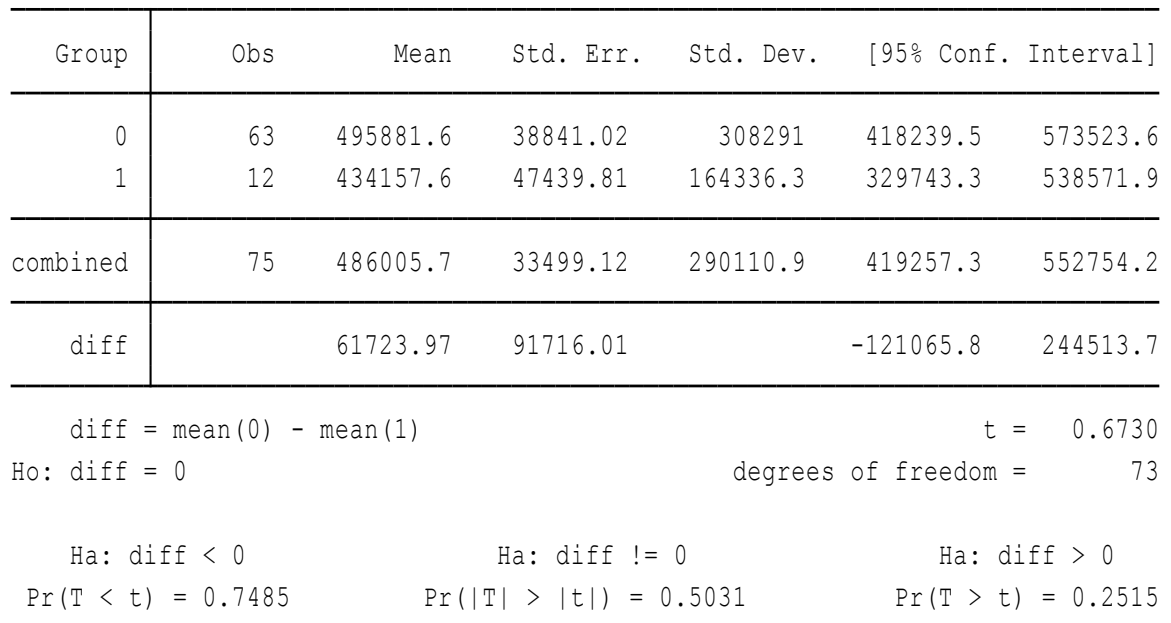

Sources: Stata Sofware 13

The results in Table 3 shows: There are 12 times of enterprises with foreign ownership participation of 10\% or more; Enterprises with $10 \%$ or above of foreign ownership have a lower S1 than others do. However, the difference of S1 between over $10 \%$ foreign owned enterprises and the remaining enterprises is not statistically significant ( $p$-value $=0.5031>0.05$, difference value 61,723.97).

Table 4: Comparison firms' facility (IET1) between firms with $10 \%$ or more foreign ownership and the rest of firms

\begin{tabular}{|c|c|c|c|c|c|c|}
\hline Group & Obs & Mean & Std. Err. & Std. Dev. & {$[95 \%$ Conf. } & Interval] \\
\hline 0 & 63 & .2405 & .0163517 & .1297872 & .2078135 & .2731865 \\
\hline 1 & 12 & .2626 & .0179034 & .0620194 & .2231948 & .3020052 \\
\hline combined & 75 & .244036 & .0140245 & .1214555 & .2160916 & .2719804 \\
\hline $\operatorname{diff}$ & & -.0221 & .0384291 & & -.098689 & .054489 \\
\hline \multicolumn{4}{|c|}{$\operatorname{diff}=\operatorname{mean}(0)-\operatorname{mean}(1)$} & \multicolumn{3}{|c|}{$t=-0.5751$} \\
\hline \multicolumn{4}{|c|}{ Ho: diff $=0$} & \multicolumn{3}{|c|}{ degrees of freedom $=\quad 73$} \\
\hline \multicolumn{2}{|c|}{ Ha: $\operatorname{diff}<0$} & \multicolumn{3}{|c|}{ Ha: diff $!=0$} & \multicolumn{2}{|c|}{ Ha: diff > 0} \\
\hline \multicolumn{2}{|c|}{$\operatorname{Pr}(T<t)=0.2835$} & \multicolumn{3}{|c|}{$\operatorname{Pr}(|\mathrm{T}|>|t|)=0.5670$} & \multicolumn{2}{|c|}{$\operatorname{Pr}(T>t)=0.7165$} \\
\hline
\end{tabular}

\section{Sources: Stata Sofware 13}

The results in Table 4 shows: There are 12 times of enterprises with foreign ownership participation of $10 \%$ or more; Enterprises with $10 \%$ or above of foreign ownership have a higher IET1 than others do. However, the difference of IET1 between over $10 \%$ 


\section{Capital Structure Evaluation, Business Size and Firms' Facility of Food and Beverage Firms Listed on the Hanoi Stock}

Exchange

foreign owned enterprises and the remaining enterprises is not statistically significant ( $p$-value $=0.5670>0.05$, difference value 0.0221).

\subsection{Correlation analysis results}

\section{Table 5: Correlation analysis results}

. correlate CS3 S1 IET1

(obs=75)

\begin{tabular}{r|rrr} 
& CS3 & S1 & IET1 \\
\hline CS3 & 1.0000 & & \\
S1 & 0.1041 & 1.0000 & \\
IET1 & -0.3085 & 0.2300 & 1.0000
\end{tabular}

Sources: Stata Sofware 13

Table 5 shows the results of correlation analysis, as known as multicollinearity analysis. The results indicate that the absolute value of each correlation coefficient between the two growth indices is less than 0.8 ; therefore, there is no multicollinearity phenomenon between the observed variables (Bryman \& Cramer, 2001).

\subsection{Capital structure situation of F\&B firms listed on HNX}

Table 6: Structure situation (debt to equity ratio - CS3) of F\&B firms listed on the HNX during the period 2015-2019

\begin{tabular}{|l|l|l|l|l|l|l|}
\hline Stock code & $\mathbf{2 0 1 5}$ & $\mathbf{2 0 1 6}$ & $\mathbf{2 0 1 7}$ & $\mathbf{2 0 1 8}$ & $\mathbf{2 0 1 9}$ & Average \\
\hline CAN & $93.70 \%$ & $96.77 \%$ & $90.85 \%$ & $124.53 \%$ & $144.44 \%$ & $110.06 \%$ \\
\hline CAP & $49.04 \%$ & $53.87 \%$ & $81.63 \%$ & $55.91 \%$ & $34.98 \%$ & $55.09 \%$ \\
\hline HAD & $14.17 \%$ & $12.05 \%$ & $144.57 \%$ & $92.62 \%$ & $35.24 \%$ & $59.73 \%$ \\
\hline HAT & $364.53 \%$ & $436.24 \%$ & $218.58 \%$ & $159.85 \%$ & $131.53 \%$ & $262.15 \%$ \\
\hline HHC & $73.17 \%$ & $53.22 \%$ & $44.90 \%$ & $157.68 \%$ & $166.50 \%$ & $99.09 \%$ \\
\hline HKB & $79.42 \%$ & $39.99 \%$ & $40.13 \%$ & $47.08 \%$ & $33.89 \%$ & $48.10 \%$ \\
\hline KTS & $18.98 \%$ & $5.12 \%$ & $113.26 \%$ & $231.57 \%$ & $139.21 \%$ & $101.63 \%$ \\
\hline MCF & $33.86 \%$ & $42.92 \%$ & $27.22 \%$ & $48.85 \%$ & $52.39 \%$ & $41.05 \%$ \\
\hline NST & $328.79 \%$ & $218.73 \%$ & $166.09 \%$ & $127.07 \%$ & $196.72 \%$ & $207.48 \%$ \\
\hline SAF & $37.91 \%$ & $50.66 \%$ & $42.96 \%$ & $56.29 \%$ & $53.91 \%$ & $48.35 \%$ \\
\hline SGC & $30.86 \%$ & $43.35 \%$ & $35.86 \%$ & $59.62 \%$ & $47.69 \%$ & $43.48 \%$ \\
\hline SLS & $32.60 \%$ & $51.25 \%$ & $117.57 \%$ & $193.93 \%$ & $158.24 \%$ & $110.72 \%$ \\
\hline THB & $63.68 \%$ & $56.94 \%$ & $106.51 \%$ & $127.66 \%$ & $98.11 \%$ & $90.58 \%$ \\
\hline VDL & $36.16 \%$ & $29.87 \%$ & $42.15 \%$ & $19.85 \%$ & $37.39 \%$ & $33.08 \%$ \\
\hline VTL & $288.35 \%$ & $318.51 \%$ & $218.77 \%$ & $147.28 \%$ & $256.05 \%$ & $245.79 \%$ \\
\hline
\end{tabular}

Sources: https://finance.vietstock.vn/ and authors synthesized

The debt-to-equity ratio indicates the degree of risk associated with how the company's capital structure is established and operated. The ratio presents how much debt a company is using to run its business and available leverage. Debt includes responsibilities and obligations established by an organization, with the aim of paying off debts over time. Debt includes short term debt which is matured within one year and long term debt which is matured in more than one year (such as, loans or mortgage).

Debt to equity ratio can help enterprise managers understand their debt situation to equity, so they can make wise decisions about critical financial strategies.

The debt to equity ratio of F\&B firms listed on the HNX, reached the average in the period $2015-2019$ from $33.08 \%$ to $262.15 \%$. This index of the enterprise with stock code HAT is $262.15 \%$, the enterprise with stock ticker VTN reached $245.79 \%$ in the whole period of 2015-2019, while the enterprise with stock ticker VDL experienced from $29.87 \%$ to $42.15 \%$ for this index. 
Capital Structure Evaluation, Business Size and Firms' Facility of Food and Beverage Firms Listed on the Hanoi Stock Exchange

\subsection{Business size situation of $F \& B$ firms listed on HNX}

Table 7: Business size situation (Revenue - S1) of F\&B firms listed on the HNX during the period 2015-2019 Unit: Million VND

\begin{tabular}{|l|l|l|l|l|l|l|}
\hline Stock code & $\mathbf{2 0 1 5}$ & $\mathbf{2 0 1 6}$ & $\mathbf{2 0 1 7}$ & $\mathbf{2 0 1 8}$ & $\mathbf{2 0 1 9}$ & Average \\
\hline CAN & 439,460 & 432,753 & 417,409 & 479,343 & 579,536 & 469,700 \\
\hline CAP & 306,864 & 322,820 & 272,608 & 388,637 & 365,865 & 331,359 \\
\hline HAD & 197,359 & 189,203 & 165,128 & 59,191 & 162,353 & 154,647 \\
\hline HAT & 529,712 & 585,223 & 590,482 & 714,067 & 813,490 & 646,595 \\
\hline HHC & 781,773 & 833,921 & 867,366 & $1,000,799$ & $1,101,424$ & 917,057 \\
\hline HKB & 434,624 & 765,121 & 139,171 & 29,374 & 1,911 & 274,040 \\
\hline KTS & 292,951 & 290,780 & 294,571 & 507,654 & 333,245 & 343,840 \\
\hline MCF & 459,701 & 422,769 & 368,685 & 547,586 & 416,779 & 443,104 \\
\hline NST & 819,790 & 802,035 & 564,164 & 611,708 & $1,015,623$ & 762,664 \\
\hline SAF & 738,197 & 877,987 & 931,099 & $1,011,363$ & $1,063,815$ & 924,492 \\
\hline SGC & 234,893 & 265,943 & 290,732 & 288,758 & 319,155 & 279,896 \\
\hline SLS & 553,141 & 0 & 537,569 & 600,730 & 879,175 & 514,123 \\
\hline THB & 534,892 & 582,145 & 580,810 & 611,853 & $1,174,440$ & 696,828 \\
\hline VDL & 428,297 & 446,562 & 591,775 & 463,811 & 309,735 & 448,036 \\
\hline VTL & 83,385 & 82,755 & 74,276 & 98,548 & 79,560 & 83,705 \\
\hline
\end{tabular}

Sources: https://finance.vietstock.vn/ and authors synthesized

Table 7 shows that the revenue of 15 F\&B firms listed on the HNX has a big difference. While the enterprise with the stock code SAF has an average turnover of 924,492 million VND in the period 2015-2019, the enterprise with the stock code VTL only reached 83,705 million VND.

\subsection{Facility situation of F\&B firms listed on HNX}

Table 8: Facility situation (density of fixed assets - IET1) of F\&B firms listed on the HNX during the period 2015-2019

\begin{tabular}{|l|l|l|l|l|l|l|}
\hline Stock code & $\mathbf{2 0 1 5}$ & $\mathbf{2 0 1 6}$ & $\mathbf{2 0 1 7}$ & $\mathbf{2 0 1 8}$ & $\mathbf{2 0 1 9}$ & Average \\
\hline CAN & $25.72 \%$ & $27.94 \%$ & $25.50 \%$ & $22.69 \%$ & $17.44 \%$ & $23.86 \%$ \\
\hline CAP & $30.85 \%$ & $25.48 \%$ & $23.44 \%$ & $20.05 \%$ & $19.64 \%$ & $23.89 \%$ \\
\hline HAD & $18.30 \%$ & $25.32 \%$ & $19.81 \%$ & $23.10 \%$ & $34.02 \%$ & $24.11 \%$ \\
\hline HAT & $13.67 \%$ & $14.17 \%$ & $16.31 \%$ & $12.90 \%$ & $14.88 \%$ & $14.39 \%$ \\
\hline HHC & $14.78 \%$ & $9.60 \%$ & $43.21 \%$ & $20.06 \%$ & $19.32 \%$ & $21.39 \%$ \\
\hline HKB & $22.84 \%$ & $9.98 \%$ & $10.13 \%$ & $12.56 \%$ & $12.99 \%$ & $13.70 \%$ \\
\hline KTS & $53.49 \%$ & $-0.74 \%$ & $16.21 \%$ & $10.30 \%$ & $12.59 \%$ & $18.37 \%$ \\
\hline MCF & $27.15 \%$ & $29.44 \%$ & $36.96 \%$ & $29.55 \%$ & $25.17 \%$ & $29.65 \%$ \\
\hline NST & $19.84 \%$ & $20.15 \%$ & $17.69 \%$ & $27.74 \%$ & $18.64 \%$ & $20.81 \%$ \\
\hline SAF & $10.03 \%$ & $44.54 \%$ & $43.44 \%$ & $56.00 \%$ & $53.70 \%$ & $41.54 \%$ \\
\hline SGC & $42.24 \%$ & $36.06 \%$ & $38.19 \%$ & $39.08 \%$ & $34.50 \%$ & $38.01 \%$ \\
\hline SLS & $33.48 \%$ & $34.07 \%$ & $39.31 \%$ & $40.17 \%$ & $44.11 \%$ & $38.23 \%$ \\
\hline THB & $35.84 \%$ & $33.28 \%$ & $35.11 \%$ & $28.17 \%$ & $27.28 \%$ & $31.94 \%$ \\
\hline VDL & $8.82 \%$ & $17.56 \%$ & $16.04 \%$ & $17.67 \%$ & $18.96 \%$ & $15.81 \%$ \\
\hline VTL & $11.48 \%$ & $13.63 \%$ & $12.50 \%$ & $13.86 \%$ & $13.13 \%$ & $12.92 \%$ \\
\hline
\end{tabular}

Sources: https://finance.vietstock.vn/ and authors synthesized

Infrastructure, machinery, equipment and technology, which is represented as the observed variable of density of fixed assets (IET1) in the F\&B firms listed on the HNX, are shown in table 8. Fixed assets in these enterprises accounted for $12.92 \%$ to $41.54 \%$ of the total assets of the enterprise. Thus, there is no enterprise that fixed assets account for $50 \%$ of total assets. There are enterprises with the proportion of fixed assets over total assets from $20 \%$ to $29.5 \%$. 


\section{Capital Structure Evaluation, Business Size and Firms' Facility of Food and Beverage Firms Listed on the Hanoi Stock Exchange}

It can be seen that some firms have not focused on investment in machine and equipment. The average proportion of enterprises also changes over the years.

\section{DISCUSSIONS AND IMPLICATIONS \\ Debt to equity ratio (CS3)}

The debt to equity ratio is used to evaluate an enterprise's financial leverage. CS3 is an important metric in corporate finance. It is a measure of the extent to which a company is financing its operations through debt relative to wholly owned funds. More specifically, it reflects the ability of shareholders' equity to cover all outstanding liabilities in the event of a business downturn. This ratio compares the company's total liabilities to shareholders' equity and can be used to examine firm's leverage level. Higher leverage tends to indicate that the company or stock is riskier for its shareholders.

The debt to equity ratio measures the company's debt to its value of net assets, is often used to gauge the extent to which a firm is indebted by utilizing its assets. The debt to equity ratio gives investors an overview of the company's financial strength, financial structure and how it can pay for its operations.

Typically, if this ratio is greater than 1, it means that the company's assets are mainly financed by debt. Otherwise, the company's assets are mainly financed by equity. In principle, the smaller the ratio is, the smaller proportion of liabilities over the total assets or capital is, which means the less probability of financial difficulties the company comes through. The larger this percentage is, the greater the chances of a company having difficulty in paying debt or going bankrupt are. Thus, among the listed F\&B firms, enterprises with stock codes VTL, NST and HAT have assets that are mainly financed by debts and probably struggle with debts settlement. The remaining companies mainly finance their assets by equity capital. This ratio of enterprises with stock codes VDL, MCF and SGC are smaller than that of other F\&B companies listed on the HNX; the liabilities of these enterprises account for a small proportion compared to their equity. Hence, these enterprises will have less probability of coming through financial difficulties.

If a large amount of debt is used to finance for growth, a company is likely to generate more than a possible income without that financing. If leverage increases income by an amount greater than the cost of debt (interest), shareholders will get benefit. However, if the cost of debt financing is greater than the incremental income, the stock's value could decrease. Debt costs may vary according to market conditions.

Changes in long-term liabilities and long-term assets tend to have the greatest impact on this ratio as they tend to be larger accounts than short-term liabilities and short-term assets. If investors want to value a firm with short-term leverage and its ability to meet its liabilities for a year or less, other ratios will be used.

\section{For the firm size factor (S1)}

On May 20, 2020, Vietnam Report Joint Stock Company announced FAST500 Ranking - Top 500 fastest growing enterprises in Vietnam in 2020. Enterprises in this ranking are sorted based on the CAGR in terms of revenue and business performance. In addition, other criteria such as total assets, total labor, profit after tax, corporate reputation on the media, and so on are also used to determine the size and position of the enterprise in the industry. Accordingly, the leading F\&B firms are the company with a growth rate of $68.69 \%$. Thus, table 7 shows that F\&B firms listed on the HNX have not reached the average revenue growth rate of the F\&B industry.

Enterprises believe that there will be many challenges in the coming period such as market fluctuations due to the impact of the Covid-19 epidemic, which could lead to the raise of competitors, increased input costs, complex administrative procedures as well as worries about uncertainties in the business environment. Vietnam's economy is likely to be adversely affected by the pandemic. In the case of a prolonged epidemic of Covid-19 which does not end seasonally, these difficulties will much more increase (Vietnam Report, 2020).

\section{For facility (IET1) factors}

Research results show that investing in fixed assets does not affect business performance. This result is not consistent with the theory and research results of Zeitun \& Tian (2007) and Onaolapo \& Kajola (2010). It may stem from the ineffective investment in fixed assets, which means invested technologies, machinery and equipment are not really suitable for food production and processing activities. It could possibly be ineffective fixed assets using of enterprises: Fixed assets have not been used up to their full capacity. In other cases, it might be that with different types of new products serving different large customers, it will be more ineffective and costlier when enterprises purchase fixed assets by themselves compared to hiring machines to perform. Moreover, when buying new fixed assets, costs of maintenance, storage and management will arise, causing capital stagnation while waiting for works for new fixed assets. 


\section{Capital Structure Evaluation, Business Size and Firms' Facility of Food and Beverage Firms Listed on the Hanoi Stock Exchange}

Changes in fixed assets and long-term financial investment of companies are often following the trend of increasing fixed assets and reducing capital in financial investment to transfer capital into production and business activities to create innovation of fixed assets and increase the rate of return. Although there is a decrease in the rate of self-financing, this is a rational problem about the capital structure of a company in the early stage of investment and business expansion. Therefore, the above transformation shows the company's focus on investment, fixed assets innovation, which is a change in line with increasing production capacity and production and business trends. It is a reasonable change that is considered one of the fixed assets solutions for F\&B firms listed on HNX.

F\&B firms listed on HNX need to adjust and do well in marketing, introducing production capacity, providing services of enterprises, step by step to dominate the market in order to receive more valuable projects to ensure the operation time of machinery, equipment and production lines. Balance tasks, arrange a reasonable production plan for each workshop and each equipment to avoid the situation that one fixed asset is working too much above capacity, while one is working too little, ensure all production workshops are always sufficient of machines and production lines.

Complete the maintenance and repair of fixed assets according to plan to minimize the possibility of failures during use. Proper maintenance, repair and use of machinery and equipment help to reduce intangible amortization and depreciation, which already proves that enterprises are effectively using a large portion of their capital. Carrying out a thoughtful maintenance and repair will prolong the life of machines, reduce downtime for repairs and increase their working capacity to ensure machines operate at full capacity.

In production and business, firms always need technology solutions to increase productivity and efficiency in all stages, including materials supply, producing organization, quality control, product promotion, product distribution, human resource management, finance, investment, and so on. Normally, technology consists of four basic components̉: Tools, machines, equipment, materials (also known as hardware of technology). Information, methods, knowledge of protocol; Organization of administration, coordination and management; People (The three later divisions are called software of technology). Therefore, listed F\&B firms need to ensure the above four components by: (i) Improving the financial potential of businesses through loans from banks and capital support from the State to research and invest in appropriate technologies for production and business processes. Strengthening cooperation and relationship with enterprises in the same industry and credit institutions to not only help businesses have more business information, but also help to expand accessible capital sources. (ii) F\&B firms listed on HNX should consider applying technology innovation in each stage. Accordingly, businesses can divide the investment process into smaller projects based on the business cycle or consider improving each stage to reduce pressure on investment capital. (iii) Strengthen links and cooperation with foreign-invested enterprises to timely grasp new standards and new techniques, to access new knowledge and technologies. At the same time, businesses need to prepare competent human resources who are capable of absorbing the outcomes of global technological progress.

\section{REFERENCES}

1) Brigham, E. F., \& Houston, J. F. (2004). Fundamentals of Financial Management, concise 4th ed., South-Western Educational Publication, Mason, $\mathrm{OH}$.

2) Bryman, A., \& Cramer, D. (2001). Quantitative data analysis with SPSS release 10 for windows: A guide for social scientists.

3) Khan, K., Qu, J., Shah, M. H., Bah, K., \& Khan, I. U. (2020). Do Firm Characteristics Determine Capital Structure of Pakistan Listed Firms? A Quantile Regression Approach. Journal of Asian Finance, Economics and Business, 7(5), 61 - 72.

4) Koralun-Bereźnicka, J. (2018). Firm size and debt maturity as indirect determinants of capital structure: evidence form European panel data. Applied Economics Letters, 25(18), 1319-1322. https://doi.org/10.1080/13504851.2017.1420869.

5) Modigliani, F., \& Miller, M, (1958). The Cost of Capital, Corporation Finance and the Theory of Investment. American Economic Review, 48, 261-297.

6) Modigliani, F. \& Miller, M. E (1963), The Cost of Capital, Corporation Finance and Theory of Investment, American Economic Review, 48, 328-336.

7) Pham, X. K. (2011). Financial analysis in Vietnam's road transport enterprises. PhD thesis, National Economics University, Vietnam

8) Vu, T. N. L. (2014). Restructuring capital at Vietnam National Oil and Gas Group. PhD thesis, National Economics University, Vietnam

9) Web: https://cafef.vn/; cophieu68.vn; https://finance.vietstock.vn/ 